\title{
A CARIDADE NA AUSÊNCIA DA CIDADANIA: ESCOLARIZAÇÃO CATÓLICA GRATUITA DE CRIANÇAS POBRES NO RIO DE JANEIRO NA TRANSIÇÃO IMPÉRIO-REPÚBLICA ${ }^{1}$
}

\author{
Marco Aurélio CorrêA Martins \\ Universidade Federal do Estado do Rio de Janeiro (UNIRIO), Rio de \\ Janeiro, Rio de Janeiro, Brasil
}

\begin{abstract}
RESUMO: A fim de compreender o papel da educação católica na sociedade brasileira é importante analisar a instrução de crianças pobres na Igreja. O conceito de caridade deve ser expandido do princípio tomista da justiça distributiva para o conceito de educação e de instrução. A escolarização de pobres fundamenta-se em documentos da Igreja e em práticas ligadas, ou não, à hierarquia católica. Houve escolas paroquiais, de Irmandades leigas, de asilos de órfãos, de ordens religiosas masculinas ou femininas, além da participação de pobres nas escolas particulares. Este artigo baseou-se em jornais das décadas de 1870 a 1920 e na literatura disponível. Na perspectiva da temporalidade histórica de Paul Ricoeur, busca relacionar a "tradição" católica e a introdução da educação escolar voltada para os desprovidos de meios próprios nas ausências do Estado no Rio de Janeiro.
\end{abstract}

Palavras-chave: Escolas católicas. Educação de crianças pobres. Educação e caridade. Caridade e direito social à educação.

\section{INTRODUÇÃO}

Para esta pesquisa delimitamos alguns marcos históricos entre a "questão religiosa" da década de 1870 e os movimentos sociais e políticos da década de 1920, no Brasil. Num primeiro período, há um crescimento da desconfiança da Igreja quanto ao Estado cada vez mais influenciado pelas ideias liberais, pois o regime do padroado havia se tornado "regalista", com a Igreja dependendo da burocracia do Império. Estando ligados histórica e constitucionalmente, os membros do clero e outros funcionários eclesiásticos eram mantidos pelo Império como funcionários públicos. Por isso, em geral, a educação católica estava relacionada ao trabalho do Estado, fosse em escolas dos mosteiros e conventos, fosse em escolas étnicas, criadas com a imigração, ou mesmo escolas criadas nas cidades e paróquias.

A "questão religiosa", como ficou conhecida, teve seu clímax com a prisão dos bispos do Pará, D. Antônio Macedo Costa e de Pernambuco, D. Vital, por desobedecerem ao Império ao não empossar mesas em Irmandades cujos membros eram da maçonaria, prática interditada por Pio XIX. O conflito pode ser compreendido como um dos diversos episódios ocorridos entre a Igreja e o Estado. Brasil (1978) considerou esse, em particular, 
uma apropriação da querela existente na Europa entre a Igreja e liberais criados e crescidos na maçonaria.

A nova nação nascida com a Independência procurou prescindir, como sempre prescindiu a colônia, de padres estrangeiros. Situação que mudou radicalmente com a separação entre Igreja e Estado promovida pela República. A vinda de religiosos, obstada pelo Império, agora estava livre à iniciativa dos bispos. O clero antes recebia côngrua dos cofres do Império; com a República, perdeu esse rendimento e os religiosos estrangeiros precisavam ganhar seu próprio sustento. Os missionários que chegavam, criavam, sobretudo, colégios, ou seja, nível secundário. Essas instituições garantiam sua sobrevivência e sua ação missionária. Apoiados na tradição católica de escolarização e na busca pelas novas classes urbanas por essas instituições, eram amparados na legislação educacional que entendia ser livre a oferta de ensino. É na conjunção desses fatores que pretendemos compreender a expansão da educação escolar católica no Brasil do final do século XIX e início do século XX.

Com a separação do Estado, a Igreja procurou se reestruturar. Essa necessidade expressa na Pastoral Coletiva dos Bispos do Brasil de 1890 (In RODRIGUES, 1981), foi quase totalmente repetida dez anos depois, indicando falta de uma liderança, dificultando essa reestruturação. Apesar disso, a Igreja buscou reaver bens eclesiásticos; introduziu novas devoções, abandonando as mais tradicionais ${ }^{2}$; algumas dioceses foram criadas e os bispos procuraram atrair o clero europeu, formados no espírito ultramontano, devido à dificuldade de formar novos padres rapidamente.

Num terceiro período, a partir do Concílio Plenário Latino-americano de 1899 e da Pastoral de D. Leme em Recife, em 1916, o esforço da Igreja se dirige mais firmemente para os colégios de religiosos, mas, também, ofereceu alternativas gratuitas de instrução primária. Essas experiências colocaram os católicos nas principais discussões de política educacional.

O Concílio Plenário Latino-americano, realizado em Roma em 1899, propôs a inserção católica na educação desde a escola primária até a superior (CONCílIO, 1899). Essa recomendação parece advir de experiências das diversas dioceses latino-americanas representadas naquele concilio, organizadas e apontadas como recomendação à Igreja do continente. Embora Carvalho (2008) aponte o direito social como o primeiro direito na experiência brasileira da constituição da cidadania, a educação escolar não foi parte dele antes das reformas da década de 1920, uma vez que a fórmula mais bem acabada da educação no direito social brasileiro aparece na Constituição de 1934: ensino público, obrigatório, gratuito e vinculação de receitas da união, estados e municípios. No Brasil independente, os direitos civis e, principalmente os políticos, não foram associados a todas as pessoas. O Segundo Império limitou os direitos políticos restringindo mais a cidadania, perspectiva mantida pela República Velha.

A pesquisa tomou como fontes os jornais de circulação no Rio de Janeiro do período em estudo. A busca nos periódicos foi realizada na rede de computadores no sítio da Hemeroteca Digital da Biblioteca Nacional. Obtivemos dados nos seguintes jornais: $O$ Apóstolo, Gazeta de Petrópolis, O Brasil, A Imprensa, Jornal do Brasil, O Paiz, Diário do Rio de Janeiro, Correio Mercantil, Almanaque Administrativo, Mercantil e industrial do Rio de Janeiro (mais conhecido como Almanak Laemmert), Gazeta de Notícias, O Dia, Cidade do 
Rio, A União, A Cruz, Correio da Manhã e Diário de Notícias, entre outros. Notamos, nesse período, 1874 a 1930, a existência de diversas iniciativas católicas de escolarização para crianças pobres. Ao todo, há mais de 650 registros relacionados às escolas ou escolarização e/ou educação da província/estado do Rio de Janeiro.

A partir dos registros, listamos as escolas, retirando dos periódicos informações sobre origem, funcionamento, localização e longevidade, quando disponíveis. Paralelamente, foram levantadas referências bibliográficas que permitiram ampliar o conhecimento e compreensão sobre essas instituições.

A partir da filosofia da história de Paul Ricoeur (2010), tentamos estabelecer temporalidades históricas para compreender as relações do horizonte de expectativa dos atores católicos do período com sua ação naquele espaço de experiência, por isso os três períodos sugeridos acima. Neste artigo, temos notado diferentes expectativas expressas nas diversas frentes de escolarização descritas, ainda que não exatamente busquemos explicitar essas temporalidades. Intentamos entender a tradição católica de atenção à pobreza, percebendo nela a inclusão do ensino e da educação em geral como obra de caridade/amor, traduzida em instituições escolares.

Na filosofia da história de Paul Ricoeur (2010), o conceito de temporalidade assume várias nuances na relação entre a existência, a narrativa e a construção histórica. Na relação entre o tempo cósmico (tempo do mundo), o tempo do calendário, os laços geracionais e outros marcadores temporais, como o monumento/documento e os vestígios, temos o tempo público, estabelecendo uma temporalidade histórica a ser descortinada pelos historiadores. Essa relação pode ser verificada através da compreensão do tempo na relação entre passado, presente e futuro. Enquanto buscamos entender a ação católica, relacionamos a mesma com alguma tradição à qual se liga e buscamos entender a que futuro projetado a iniciativa se ligava. Novas temporalidades podem ser notadas na mudança de iniciativas, referentes ao presente, na expectativa de futuro ou na relação estabelecida com o passado.

\section{A QUESTÃO DA POBREZA E A ESCOLARIZAÇÃO DE POBRES}

No período pesquisado, há crescente procura pelas classes médias urbanas por educação como fonte de ascensão social. O tema da educação das elites é detalhado na história da educação, mas resta discutir quem é essa elite e, agora, quem é esse pobre. As classes médias urbanas e as famílias abastadas das regiões rurais foram fontes de financiamento das escolas, via mensalidade escolar, pensão ou quaisquer outros meios.

Os colégios do século XIX podiam ser de tempo integral, com internato ou semiinternato e externato. Embora muitas iniciativas procurassem dar condições de acesso aos mais desafortunados, o pagamento de mensalidades já nos autoriza a dizer que esses colégios não estavam acessíveis aos pobres. A instrução escolar para todos não era regra no Brasil do século XIX. Assim, apontamos a existência de alunos pobres nas escolas da elite. De outro modo, a educação básica, primária, não se dava somente nos colégios, nem era sua principal função, os colégios ocupavam-se do ensino médio (CONCEIÇÃO, 2012). Em alguns períodos, é difícil separar a atuação das instituições nesse campo, uma vez que os modelos são variados: escolas isoladas, de larga tradição no Brasil e o colégio, modelo preferido pela elite e pelos religiosos de origem europeia. 
Para os pobres, muitas iniciativas civis, religiosas e públicas procuravam oferecer escolarização primária gratuita. Na Igreja, as Irmandades leigas, Ordens Terceiras, Conferências Vicentinas, Paróquias e as Ordens Religiosas foram os principais agentes dessa obra. No plano público, além das escolas estatais, várias escolas particulares foram subvencionadas com contrapartida de matrículas gratuitas.

Podemos destacar três tipos de alunos pobres: o filho trabalhador urbano, de baixa renda; os ingênuos e filhos das famílias oriundas da escravidão; e o órfão, cuja tradição de atenção remonta a instituições coloniais brasileiras. Parece-nos importante ressaltar a preocupação em escolarizar essas crianças, ainda que a escolarização culmine em profissionalizar. Disso falaremos adiante.

\section{ESCOLARIZAÇÃO DE POBRES JUNTO ÀS ELITES}

Nossas pesquisas nos jornais mostram haver mais do que colégios de ordens religiosas, embora fossem essas as preferidas das classes médias urbanas e elite. Pasche (2014) procurou estabelecer relação entre o Estado e a Igreja na prestação de serviços de instrução, ou "comércio da instrução", como conceituou. Sua abordagem permitiu percebermos a existência de escolas particulares pertencentes a membros do clero secular. Diversamente das escolas de congregações religiosas, as do clero secular tiveram seu apogeu no período do Império. Essa constatação nos remete a uma das possibilidades da temporalização sobre a qual nos debruçamos. Essas escolas particulares do clero secular não parecem guardar uma relação entre si ou com a hierarquia da Igreja. Contudo, atendem à demanda da sociedade e aos requisitos públicos estabelecidos pela Reforma Couto Ferraz de 1854, como incumbir aos párocos da instrução primária, quando não houvesse escola pública na paróquia entregando, se necessário, a particulares (BRASIL, 1854).

Pasche (2014) nos deu uma lista com 10 colégios ou escolas de padres entre 1860 e 1880. A esses acrescentamos um, trazido por Conceição (2013), e mais três, encontrados em anúncios do Laemmert e outros jornais entre 1895 e 1902.

As escolas ligadas a ordens religiosas foram listadas por Moura (2000), a partir de uma pesquisa da Associação Nacional de Mantenedoras de Escolas Católicas (ANAMEC), de 1996. Para o Rio de Janeiro, foram listadas 29 escolas entre 1850 e 1930. Essas escolas cresceram exponencialmente a partir da República, mormente após a Primeira Guerra. Nacionalmente, as escolas listadas para o Império eram 17 e houve acréscimo de 30 na primeira década de República. Na década subsequente, mais 70 escolas foram criadas. Entre 1911 e 1920 foram estabelecidas outras 72 e, entre 1920 e 1930, foram mais 101 escolas. No Rio de Janeiro, o maior incremento dessas escolas foi na década de 1910 . Na pesquisa ANAMEC não constam as escolas extintas e algumas que não responderam ao questionário, porém, os dados nos permitiram perceber uma mudança na escolarização católica a partir da República.

Embora particulares e mantidas por mensalidades, nas escolas de religiosos notamos a presença de alunos pobres. Por isso levantamos a seguinte questão: como uma ordem de carisma voltado para os pobres, como as Filhas da Caridade (Irmãs Vicentinas), ou os padres da Congregação da Missão (Padres Lazaristas), dedicaram-se à educação de 
moças e rapazes das classes médias urbanas e da elite, provavelmente da elite cafeeira, nos internatos? As escolas religiosas são a base material da subsistência da ordem no serviço missionário, já o dissemos. Por exemplo, as Irmãs Vicentinas em Botafogo mantiveram asilos para meninos, distribuição de víveres, pensão para senhoras etc. Arruda (2011, p. 79), referindo-se à criação do Colégio Nossa Senhora das Dores, 1898, em São João Del Rei, pelas Filhas da Caridade, afirmou que um duplo sentido embasava aquela empresa: arrecadar recursos para a Santa Casa, à qual cabia cuidar de doentes pobres e órfãos, além de cuidar da formação moral e espiritual das futuras mães de família. Dessa dupla compreensão da caridade trataremos mais adiante.

Sob o argumento da formação moral e espiritual, pode-se compreender o trabalho das "Martinhas" ${ }^{\text {"3 }}$ do Colégio de Sion em Petrópolis (ALAMINO, 2008). Elas trabalhavam no colégio como forma de pagar pela pensão e estudo:

As "Martinhas" realizavam diversos serviços dentro do Colégio: trabalhavam na rouparia, na limpeza dos quartos e banheiros, na cozinha, etc. O tempo de trabalho ao longo do dia era superior ao tempo de estudos, pois as mesmas dedicavam, em média, apenas três horas diárias para esta última atividade. Os espaços ocupados por elas também eram diversos com relação aos espaços ocupados pelas "Meninas de Sion" - os dormitórios, o refeitório, os banheiros e até as salas de aula eram separados. Tem-se que ressaltar também que não poderia haver contatos entre as "Meninas de Sion" e as "Martinhas" (LAGE, 2006, p. 11).

Havia uma visão "moral" da pobreza. Os pobres não eram compreendidos pelo prisma econômico e social, mas em uma posição escatológica. O Padre Júlio Maria, em sua conferência "D. Bosco e o Pobre", em 1899, apontou a necessidade de aliviar o proletariado e a pobreza como um dos principais problemas sociais. Afirmou ainda que D. Bosco teria compreendido o pobre em sua precedência hierárquica na Igreja, da qual dependeria o rico para sua salvação, enquanto o pobre dependeria do rico não só pela caridade, mas pela justiça, para sua subsistência, por isso a necessidade de convivência das classes (JÚLIO MARIA, 1986). Júlio Maria retomava posições teológicas originárias dos mendicantes e do tomismo em defesa dos pobres e dos "novos pobres", os operários. Conceição $(2012$, p. 252) citou o romance As três Marias, de Rachel de Queiroz, sobre observar as meninas órfãs do colégio, bordando os enxovais para as moças mais ricas, "porque elas eram as pobres do mundo e aprendiam justamente a viver e a penar como pobres". Mollat, por sua, vez, ao analisar o declínio dos mendicantes no século XIV, percebeu o desprezo pela pobreza, vendo nela fraqueza, repugnância e uma vergonha. Mesmo com a mudança de visão causada por São Francisco de Assis no século XIII:

Por um lado, aconselha-se ao desvalido que assuma sua desdita com paciência, pois foi isso o que lhe coube com a permissão de Deus. Por outro lado, embora a caridade seja reconhecida como uma virtude e a beneficência como um dever, o exercício de ambas permanecia impregnado de soberba, de um verdadeiro desprezo humilhante. A comiseração não se confunde com a compaixão (MOLLAT, 1989, p. 72).

Não se pode hoje citar, sem horror, as "Martinhas" de Sion, as quais, segundo Alamino, (2008) eram "invisíveis". Mas essas meninas não só alcançavam sua redenção se- 
gundo a compreensão cristã, como melhoravam suas chances de inserção social nos mecanismos próprios daquele tempo: um patriarcado no qual o casamento e/ou os serviços domésticos para uma classe socialmente superior seria o "destino" das moças e, para o qual, portanto, eram preparadas. Alamino apresentou alguns depoimentos positivos das ex-"Martinhas" sobre tudo isso.

Também no Colégio Imaculada, em Botafogo, havia pobres. Limeira (2010, p 193.) citou um ofício do delegado da instrução da Freguesia da Lagoa, na capital, atestando haver nove colégios particulares naquela região. Segundo o documento, o Colégio Imaculada tinha, no ano de 1872, 230 alunas, sendo 80 delas gratuitas, sem as expensas dos cofres públicos; um número expressivo de cerca de $35 \%$ das moças.

A presença de pobres nas escolas religiosas ou dos padres seculares se deu, também, através de subvenções públicas, sendo essa a política de escolarização do Império, desde a Reforma Couto Ferraz de 1854. Os relatórios apresentados por Jose Theodoro de Azambuja, delegado da Lagoa, (Apud LIMEIRA, 2010, p. 192) mostram uma subvenção de 20 alunos na Escola da Irmandade de Nossa Senhora de Copacabana, em 1872. Dois anos depois, segundo a mesma autora, a subvenção de, no máximo, $100 \mathrm{mil}$ réis para 30 alunos. A Irmandade de Nossa Senhora da Conceição na Gávea, em 1875, possuía uma subvenção de 92 mil réis (LIMEIRA, 2010, p. 213). O Colégio Salesiano de Niterói recebeu da Província uma subvenção de 10 contos de réis, em 1886, para 20 alunos. A proposta original era de 20 contos (AZZI, 1983, pp. 59-61).

Em Petrópolis, franciscanos recebiam isenções de impostos da prefeitura para sua escola paroquial fundada em 1896, além de isenção de imposto e taxas de alfândega pelo governo da República. Essa escola foi largamente noticiada na Gazeta de Petrópolis.

\section{ESCOLAS DE IRMANDADES, CONFRARIAS OU ORDENS LEIGAS}

As Irmandades leigas, herdeiras da tradição católica colonial, tiveram significativa participação na oferta de escolarização, sobretudo na cidade do Rio de Janeiro. Entre 1849 e 1925 encontramos 15 menções a escolas ligadas a movimentos leigos: nove irmandades, sendo duas delas exclusivamente de negros; duas Ordens Terceiras; duas Devoções Particulares e duas Conferências Vicentinas.

Acreditamos que elas são as principais respostas dos católicos leigos aos desafios da escolarização urbana nos moldes pretendidos pelo liberalismo do final do século XIX, para o qual a escolarização devia ser buscada pelo indivíduo como forma de pertencimento ao mundo político e civilizado. No entanto, não apenas a sociedade civil reivindicava essa participação, mas o Concílio Plenário Latino Americano já havia conclamado a criar escolas católicas para combater a escola estatal, protestante e maçônica, dentre outras.

Para Soares (2011), ao analisar as eleições nas Irmandades de homens pretos do Rio de Janeiro no século XVIII, a participação e representação no interior dessas irmandades eram formas de desfrutar de alguma liberdade (pois se tratava de maioria cativa), experimentada como privilégio, no interior de uma sociedade onde a liberdade universal não podia ser exercida. Dessa forma, na Irmandade analisada por ela, São Elesbão e Santa Efigênia, havia um sistema de representação e voto nos quais livres e ca- 
tivos, homens e mulheres exerciam a participação direta, interditada na sociedade global. Essa Irmandade manteve por um período uma escola para seus irmãos. Contudo, o professor dessa escola a deixou para assumir outra na Irmandade do Rosário e São Benedito em 1900 (O PAIZ, 1900, p. 2).

Pinheiro (2011), ao tratar da questão da educação dos ingênuos pelo jornal $O$ Apóstolo, deixou clara a posição editorial em favor da abolição gradativa com a necessária educação do ingênuo e mesmo do cativo antes da abolição definitiva para que se ajustassem à sociedade. Para tanto, seria necessária a criação de escolas públicas de inspiração católica já que, como denunciava o periódico, os senhores de escravos não cumpriam, com a Lei do Ventre livre, a obrigação de cuidar da educação dos ingênuos e, tampouco, o Império fiscalizava o cumprimento da lei. A indicação do texto de Pinheiro permite-nos identificar alguma oferta de escolarização por leigos, principalmente pelas irmandades e paróquias.

Na Irmandade de Nossa Senhora do Rosário, a criação de uma escola para os filhos dos irmãos falecidos era um dever inscrito como de caridade no "Compromisso" da associação. Como afirmou Cunha (2004), desde 1839 havia a proposta de criação de uma escola, só efetivada em 1883. A autora revela a convicção de a Irmandade estar às voltas, com o pensamento corrente, da necessidade da inclusão do indivíduo na participação civil e política pela escolarização primária, através da leitura e da escrita.

O sentido ou sentimento da caridade revela a inclusão da escolarização como meio de sobrevivência e subsistência nessa sociedade do XIX e nos reporta à ausência do direito social e à sua necessidade. Não apenas um direito voltado para o acesso a essa espécie de "benesse" moderna, mas, acima de tudo, a previdência ou os mecanismos de garantias de sobrevivência aos "desprovidos pela sorte". Essa era a aposta das instituições escolares católicas voltadas para a profissionalização e outras criadas no interior de instituições de abrigo de crianças e adolescentes.

Enquanto as irmandades procuravam atender a seus associados, por iniciativa das conferências de Vicentinos foi criada uma escola no morro do Castelo e outra que funcionou na Rua Visconde do Rio Branco, mudando-se, posteriormente, para a Rua do Lavradio, no Rio de Janeiro. A Sociedade São Vicente de Paulo era um modelo diferente das Irmandades, pois não atendia apenas a associados, embora tivesse uma lista de pessoas atendidas pelas chamadas "Conferências Vicentinas". A Escola Gratuita São Vicente de Paulo possuía uma Associação com o fim exclusivo de manter a escola.

Chamou-nos muito a atenção o destaque dado à escola da Rua Visconde do Rio Branco pelos jornais de José do Patrocínio, Gazeta da tarde e Cidade do Rio. Anteriormente, esse jornalista, líder abolicionista, deu ênfase à Escola de São Benedito, mantida pela Irmandade de Nossa Senhora do Rosário e de São Benedito, o que nos permitiu cogitar sobre a atenção à família de ingênuos e ex-escravos. Curiosamente, essa escola teve um jornal próprio chamado O Correio Familiare, posteriormente, O Educador.

\section{ESCOLAS PROFISSIONALIZANTES}

A educação profissional no Brasil nasceu permeada por um caráter assistencialista e moralizador, visando a transformar o homem através do trabalho. Oferecer algum tipo de educação para o trabalho era uma forma de tirar os pobres e des- 
validos de sua condição de miséria e torná-los uma força capaz de contribuir para o progresso do país. Além disso, segundo Franco (2011), a pobreza traz para o século XVIII a questão da vadiagem e, no caso do Brasil, referenciava os livres, de ascendência africana, apesar dessa mesma condição de vadio, atribuída ao mestiço, ter sido minimizada pela geração iluminista da década de 1790.

Apesar de a profissionalização ser usada como uma ferramenta para alavancar a nação, Santos (2010) diz que a natureza da discriminação do trabalho manual está na forma de inserção do trabalhador na sociedade. Nosso histórico escravagista fez com que todo o trabalho relacionado ao uso da força e das mãos fosse rejeitado pelos homens livres. Como o público da educação profissionalizante está entre os pobres e desvalidos, percebemos as ações da Igreja na área.

Os Salesianos foram os importantes protagonistas da educação profissional em Niterói a partir de 1883. No Colégio Santa Rosa funcionavam oficinas de sapataria, marcenaria, pintura, tipografia etc.: além do ensino das primeiras letras e das ciências, profissões de interesse urbano-industrial. Também faziam parte das atividades do colégio momentos de música, teatro e jogos: os Oratórios Festivos serviam de atrativo aos jovens pobres e desamparados para o estabelecimento (AZZI, 1982).

Ao contrário dos Salesianos e Franciscanos que educavam meninos para a sociedade urbano-industrial nos moldes republicanos, a Escola Doméstica Nossa Senhora do Amparo, em Petrópolis, educava meninas para tarefas domésticas nos moldes da nobreza imperial. O Padre Siqueira foi o fundador da Escola Doméstica, inaugurada em 1871, que tinha como objetivo atender meninas órfãs ou pobres. As meninas eram ensinadas nas primeiras letras e nas quatro principais operações matemáticas; além disso, eram ensinadas para os chamados "arranjos domésticos" como, costura, bordado, lavar, passar, engomar... Tal educação visava a formar meninas nas atividades domésticas e encaminhá-las a um emprego ou ao casamento e, em certos casos, à docência (HÓSTIA, 1957).

A escola dos franciscanos em Petrópolis, além de ser uma escola de religiosos, era uma escola paroquial, étnica e também exercia atividades profissionalizantes. Contudo, não tinha o carisma específico das escolas salesianas e da Congregação Franciscana do Amparo, também fundada pelo Padre Siqueira para cuidar da Escola Doméstica. Da escola dos padres franciscanos surgiu uma empresa gráfica e editora, a Vozes, e um coral, os Canarinhos de Petrópolis; frutos do desejo desses religiosos em dar direção profissional, além de religiosa e social, a seus alunos.

A participação católica com escolas étnicas e profissionalizantes denota uma razoável abertura da Igreja e dos católicos para as questões próprias de seu tempo, mormente a questões urbanas. $O$ mesmo se poderia deduzir da participação de padres à frente de colégios no terceiro quartel do séc. XIX e em órgãos estatais de controle da escolarização (cf. PASCHE, 2014).

\section{ESCOLAS EM ASILOS, EDUCANDÁRIOS, ORFANATOS}

Esse termo de escolas e educandários é muito geral e abarca muitas instituições. Algumas escolas e colégios começam como asilos ou educandários, outros são asilos e 
colégios ao mesmo tempo. A escolarização dessas crianças tem o mesmo fim daquele projetado pela educação profissionalizante e visava, dentre outras coisas, a dotar os órfãos de melhores condições frente à sociedade, também quanto à capacidade de autogestão de suas vidas após o asilamento. Várias instituições para órfãos e desvalidos, como também a Santa Casa de Misericórdia do Rio de Janeiro, possuíam escolas para as crianças. Mesmo instituições públicas buscavam, principalmente nas religiosas (freiras), educadoras para a infância asilada. Era, por exemplo, o caso de um asilo público em Niterói no século XIX, o Asilo Santa Leopoldina. A Santa Casa também recebeu as Irmãs de caridade para cuidar dos doentes e "expostos" para os quais, lá, mantinham uma escola. A Irmandade da Candelária criou um educandário no bairro de São Cristóvão a partir do espólio do comerciante Gonçalves Araújo. Todas essas instituições aparecem em notícias dos jornais do período. Nessa mesma região, intentou-se criar um asilo para meninos recolhidos pela polícia a ser cuidado pelos padres Salesianos que recusaram o ofício (AZZI, 1983). Nossa pesquisa não produziu uma listagem suficiente dessas instituições.

\section{ESCOLAS PAROQUIAIS}

As escolas paroquiais são uma forma antiga de educação cristã. Remonta à Idade Média e nelas estão as origens das universidades medievais. No Rio de Janeiro do século $\mathrm{XIX}$, encontramos três dessas escolas e, no século XX, oito. No entanto, algumas escolas de religiosos são também escolas paroquiais como a dos franciscanos em Petrópolis.

Na década de 1920, a pretexto de comemorar o jubileu sacerdotal do Cardeal Arcoverde, D. Leme deu início, na "Ação Católica", à Liga Patriótica dos Católicos Brasileiros, responsável por criar e manter cerca de 70 escolas para pobres: crianças e adultos de ambos os sexos. Muitas dessas escolas eram paroquiais e mantidas pela Liga, mas havia outras mantidas pelas ordens religiosas presentes na cidade, por particulares leigos ou pelas próprias paróquias. Essas escolas aparecem largamente nas páginas do jornal $A$ Cruz, além de outros.

Considerando ter encontrado maior número de escolas no século XX, atribuímos a iniciativa ao Concílio Plenário Latino Americano ao estimular a criação dessas escolas de ensino primário nas paróquias. Esse Concílio, convocado em Roma por Leão XIII, tentou organizar a hierarquia católica latino-americana em torno de um projeto ultramontano. Os documentos desse Concílio se tornaram constituição eclesiástica da Igreja latinoamericana. No Brasil, foram substituídas em 1915 por Concílios regionais da Bahia e do Rio de Janeiro.

\section{EDUCAÇÃO COMO ATO DE CARIDADE}

Entendemos que a caridade é um tema católico no século XIX e início do século $X X$, no contexto em análise, devido às questões suscitadas pelo desenvolvimento do capitalismo industrial e urbano. Sob esse tema, a educação é tratada com duplo sentido: educação dada pela família e instrução dada pela escola, sendo esta submissa àquela ${ }^{4}$. Contudo, devido à sua visão de salvação, a Igreja estipula uma submissão da educação e da família à religião. Educa-se para a vida eterna e para a vida na Terra, mas prevalecem os valores morais e religiosos em sua escatologia. 
Educar é um gesto caritativo e, portanto, dever moral e religioso daqueles que estão à frente da evangelização. A caridade se dá em duas direções: em relação ao pobre, representante da pobreza de Cristo, e em relação ao educando, sedento das graças do saber e da ciência de Deus e dos homens.

É marcante nos discursos entre os religiosos a vinculação da educação à caridade. Ou seja, "educar" é um ato caritativo. E, nesse caso, a caridade não é restrita aos pobres, caracterizados socioeconomicamente, já que a caridade se aplica a todo tipo de carências. Educar seria distribuir o saber como melhor viver e alcançar a salvação.

Em 1933 o jornal A Cruz, publicado na Paróquia de São João Batista, em Botafogo, órgão da Ação Católica, no intuito de demonstrar que a Igreja sempre fora a favor da instrução, aponta em seus argumentos o seguinte:

Se incluiu entre as "obras de misericórdia" a de "ensinar os ignorantes", não só as letras religiosas, a instrução cristã, mas do mesmo passo a instrução profana, preceito que nunca deixou cair no esquecimento, sempre avivado e posto em prática[.] Como pode haver alguém, medianamente instruído e sincero, que negue este fato? (A IGREJA, 1933, p. 1).

O século XIX nos legou, com bastante ênfase, a necessidade da instrução, de modo que, em algum lugar do século XX, passamos a identificar escolarização e instrução como educação ${ }^{5}$. Assim, se é função da caridade dos pais e dos mestres educar os mais jovens, é caridade dos professores instruírem seus alunos. Na Rerum Novarum, assim resume o Papa Leão XIII (1891):

Quem quer que tenha recebido da divina Bondade maior abundância, quer de bens externos e do corpo, quer de bens da alma, recebeu-os com o fim de os fazer servir ao seu próprio aperfeiçoamento, e, ao mesmo tempo, como ministro da Providência, ao alívio dos outros.

Em Santo Tomás de Aquino, caridade é um nome que se dá ao amor. Para nós, é esclarecedora a exploração de Bigo (1969) sobre a questão da caridade em Santo Tomás de Aquino. A esmola é a forma de colocar em disponibilidade um bem que pertence à comunidade por ultrapassar à necessidade de quem o obteve $e^{6}$. Desse modo, os bens produzidos pela comunidade deveriam ser distribuídos nela mesma. No entanto, isso não aconteceu como um direito social, mas como um preceito do direito natural. Nesse contexto, a justiça se tornou difícil de exercer se cada um define por si, subjetivamente, a esmola dada. Por isso, desenvolveu-se uma visão moral por ausência da economia política. Por extensão, passamos dos bens materiais aos "espirituais". Para o Padre Júlio Maria, em 1895, competia ao clero ensinar a doutrina ao povo, era um dever de caridade e de justiça (JÚLIO MARIA, 1934). Para D. Leme, em 1916, "sempre que houver inteligências que instruir, tenhamos boca para ensinar" (LEME, 1916, p. 72).

A instrução tende para as questões práticas, materiais, da vida social. De modo que o instruir passou a identificar-se com o "progresso" material da sociedade: melhorar a posição social, no caso dos mais pobres, através de uma instrução que lhe permitisse melhores colocações no mundo do trabalho. Em 1905, o Pe. Júlio Maria ensinou que era 
preciso o jovem preparar-se para mudar o mundo; era preciso estudo para fortalecer a razão com esclarecimento e a vontade com firmeza, pois a razão esclarecida não podia prescindir da vontade firme e vice-versa. (MARTINS, 2013).

Júlio Maria notava um processo de mudança social construído através da instrução, ou estudo, como disse. Mas tem que se atentar para a presença da visão contrária, a manutenção da ordem social. Vai mudar o mundo, mas é necessário certo conhecimento; e tanto o conhecimento como a mudança devem ser compartilhados. É preciso ter em mente que a visão católica sobre a divisão social ainda era devedora da compreensão estamental e da origem divina da sociedade.

Uma questão sobre a caridade é o papel reivindicatório do necessitado. Assim como a máxima que ecoa nos corredores do judiciário, "o direito não socorre os que dormem", a caridade distributiva só ocorre mediante a reivindicação. Tal solicitação pode ser feita pessoal e diretamente, ou por intercessão da Igreja e de seus prelados. Nesse pressuposto, o bispo teria se tornado, na baixa Idade Média, o "pai dos pobres" e as ordens mendicantes atuaram no fim da Idade Média e no Renascimento (MOLLAT 1989). Ainda sobre essa questão, São Francisco de Assis teria respondido a um interlocutor sobre pedintes que exploravam a boa fé dos caridosos. Para o Santo, cabia ao juízo divino tal consideração, enquanto que ao esmoler caberia entregar ao que pede e não avaliar sua necessidade. (cf. LE GOFF, 2013). No entanto, para o tempo moderno, como afirma Franco (2011, p. 232-233), a caridade moderna estabeleceu que ela não podia, nem devia ser aplicada a todos; por exemplo, no Brasil do século XVIII, o escravo era responsabilidade de seu senhor e os mestiços, associados à vadiagem; ambos eram excluídos da caridade e das misericórdias. Segundo esse autor, ser escravo era um dado jurídico enquanto ser pobre era uma condição sem estatuto e sujeita a avaliações individuais e coletivas.

Embora o projeto da caridade seja atender aos necessitados, conforme a descrição das misericórdias derivadas do Evangelho de Mateus, capítulo 25, a história poderá apontar privilégios sociais aqui e acolá sem que o ideal seja contestado. Assim sendo, a caridade não é para todos, mas para os necessitados, os "pobres de Cristo". No entanto, como procura mostrar Franco (2011), serão excluídos da caridade (ou das misericórdias) alguns necessitados em função de seletividades que vão sendo instituídas nas desigualdades da sociedade moderna e, para o caso brasileiro, foram excluídos escravos e vadios.

Como vimos notando, a caridade é tema da lgreja desde seus primórdios. No entanto, o liberalismo clássico aponta a solução das questões da pobreza para a sociedade e não para o Estado, por isso a ausência de uma cidadania plena, nos termos propostos por Marshall (1967) no Brasil do séc. XIX e início do séc. XX7. Embora haja aparente coincidência, não se deve tomar a caridade dos liberais pela da Igreja, uma vez que o projeto da Igreja é estamental e comunitário, enquanto o dos liberais é capitalista e classista. Essa identificação também não deve ocorrer quanto à questão do "ensino livre", já que a Igreja não defende as liberdades liberais, mas se apropria da condição legal e política da educação para combater o Estado na educação, promovendo suas próprias instituições escolares.

A oposição católica ao liberalismo político e econômico se traduziu na adesão a uma filosofia neotomista, ainda que tenha relações não oficializadas com a filosofia tradicionalista ${ }^{8}$. Diante do Estado laico proclamado com a República em 1889, a Igreja pas- 
sa a combater a escola pública como a-católica, do mesmo modo que combatia, sob a mesma nomenclatura, as escolas protestantes e espíritas. Sendo pecado enviar os filhos a escolas a-católicas, propôs a criação de escolas alternativas.

\section{CONSIDERAÇÕES FINAIS}

À guisa de compreender a participação católica na transição do Império à República quanto à educação e sua inserção no modo brasileiro de educação pública, considerado na ausência de um sentido universalizante para a escolarização, encontramos, nas pesquisas em jornais, alusões a escolas gratuitas e vagas gratuitas em escolas particulares. Ao listar essas instituições, procuramos compreender sua inserção no movimento social, político e educacional no século XIX, o qual foi extensivo ao início do século $X X$, qual seja, a educação como iniciativa da sociedade com participação estimuladora do Estado, principalmente no período da Primeira República.

Dada a recusa católica às ideias liberais, embora usufruindo de sua principal referência, o livre-ensino, procuramos quais seriam os fundamentos da Igreja para ofertar escolas gratuitas aos pobres. Encontramos esse fundamento na ideia de caridade pela qual se faz a distribuição na comunidade dos bens recebidos por meio dela, através do trabalho de seus membros, na medida do que ultrapassa a sua necessidade individual. Foi possível perceber, assim, o sentido de caridade na ação de educar, nela incluída a ação de instruir. Além desse sentido mais abstrato, a caridade também explica como dotar o indivíduo de meios para sua subsistência na sociedade, principalmente quando órfão e pobre, a fim de sobreviver pelo trabalho, sem as expensas de esmolas. Um terceiro dado, não explorado neste texto, é a relação entre o alívio da pobreza ao combate à delinquência.

Esta pesquisa não nos permite falar da longevidade das instituições educacionais caritativas ou das vagas gratuitas nas escolas particulares, tampouco da subvenção estatal para as mesmas, devido à limitação da fonte em apresentar todos os dados necessários. Contudo, pela exposição jornalística, é possível estabelecer as relações sociais, políticas e eclesiais dessas instituições nos projetos de educação no período percorrido, a fim de melhor estabelecer o contraste com o projeto de educação pública propugnado a partir das reformas da década de 1920 nos estados brasileiros. Este é um projeto ainda em andamento, qual seja, de uma escola pública e gratuita com função social acessível a todo cidadão.

Conhecer a escolarização católica de pobres é um importante desafio de pesquisa. É preciso aprofundar as informações sobre as instituições ligadas a esses projetos de escolarização dentro e fora da Igreja, de maneira principal quanto às iniciativas leigas. Além disso, deve merecer mais atenção as formas de financiamento das escolas católicas nesse período. Neste texto apenas acenamos a isso. 
CHARITY IN THE ABSENCE OF CITIZENSHIP: FREE CATHOLIC SCHOOLING FOR POOR CHILDREN IN RIO DE JANEIRO ON THE TRANSITION EMPIRE-REPUBLIC

ABSTRACT: In order to understand the role of catholic education in brazilian society it is important to look at poor children's teaching in the Church. The concept of charity must be expanded from the tomist principle of distributive justice to the education and teaching concepts. The schooling for the poor is based on the Church documents and linked, or not, to catholic hierarchy practices. There were parochial schools runned by Lay Brotherhoods, asylums, orphanages, masculine and feminine religious orders, besides the participation of the poor in private schools. This article was based on the newspapers from 1870 to 1920 decades and the available literature. In the historical temporality perspective of Paul Ricoeur is sought to relate the catholic "tradition" and the introduction of schooling to the deprived of livelihoods in the absence of the Rio de Janeiro State.

KEYWORDS: Catholic schools. Poor children education. Education and charity. Charity and social rights to education.

\section{LA CARIDAD EN LA AUSENCIA DE LA CIUDADANÍA: ESCOLARIZACIÓN CATÓLICA GRATUITA A NIÑOS POBRES EN RIO DE JANEIRO EN LA TRANSICIÓN IMPERIO-REPÚBLICA}

RESUMEN: Para comprender el papel de la educación católica en la sociedad brasileña es importante volver a la educación de niños pobres en la Iglesia. El concepto de caridad debe ser ampliado de el principio tomista de la justicia distributiva para el de educación y de instrucción. La escolarización de pobres se basa en documentos de la Iglesia y en prácticas relacionadas, o no, a la jerarquía católica. Había escuelas parroquiales, de cofradías laical, de asilos de huérfanos, de órdenes religiosas masculinas o femeninas, así como la participación de los pobres en las escuelas privadas. Este artículo fue basado en periódicos de las décadas de 1870 a 1920 y en la literatura disponible. Teniendo en cuenta la temporalidad histórica de Paul Ricoeur, trata de relacionar la "tradición" católica y la introducción de la enseñanza escolar destinada a aquellos privados de sus propios medios en las ausencias del Estado en Río de Janeiro.

PALABRAS CLAVE: Escuelas católicas. Educación de niños pobres. Escolarización y caridad. Caridad y derecho social a la educación.

\section{NOTAS}

1) A presente pesquisa foi financiada pela FAPERJ, através de um auxílio instalação, e pela UNIRIO, através do programa institucional de Iniciação Científica.

2) Alguns historiadores, como Comblin e Beozzo, indicaram esse processo como regido por uma política eclesial chamada de ultramontanismo, mas marcando uma desvalorização da cultura popular (Cf . DELLA CAVA, 1975, SANTIROCCHI, 2010 e DUTRA NETO, 2006). Ao contrário, seria melhor entender que o catolicismo popular brasileiro era totalmente fora do controle eclesial. $\mathrm{O}$ que importa é o controle e não a visão da cultura popular. Parece-me, assim, mais plausível que a 
substituição das tradicionais devoções por novas, trazidas pelos religiosos europeus adeptos do ultramonismo, atraem o interesse popular e evita os desgastantes atritos institucionais com os leigos. Movimentam-se de um catolicismo fora do controle da hierarquia para uma devoção popular eclesialmente condicionada pela visão ultramontana da Igreja.

3) O nome "Martinha" era uma referência ao Evangelho Lucas 10,40; enquanto Marta trabalhava nos afazeres da vida comum, Maria seguia os homens nas pregações de Jesus.

4) Essa relação será explicitada definitivamente pela encíclica Divini llius Magistri, do Papa Pio XI em 1929. A encíclica incluiu o Estado nessa relação, sempre visto com desconfiança pela Igreja.

5) Supomos importante para compreender essa relação a imbricação proposta por Herbart, no final do XIX, através da ideia de "educar pela instrução" ou "instrução educativa" (HILGENHEGER, 2010).

6) Através da Encíclica Aeterni Patris, de 1879, Leão XIII restabelece o laço da filosofia tomista como filosofia oficial da Igreja. Porém, uma nova interpretação desse tomismo recebeu o nome de neotomismo na filosofia.

7) Segundo Marshal (1967), a história da cidadania na Inglaterra passa pela consolidação dos direitos civis que levaram à consolidação dos direitos políticos na sequência e, por consequência, esse último ao direito social. A análise de Carvalho (2015), trazendo essa questão à história brasileira, atesta a consolidação do direito social apenas no pós-1930 e sob governos autoritários, muitas das vezes suprimindo direitos políticos e civis. Portanto, há ausência dos direitos sociais no período analisado por esta pesquisa.

8) A filosofia tradicionalista, reacionária à Revolução Francesa, coloca na ordem o sentido da conservação da tradição. No Brasil, no caso dos tradicionalistas católicos do século XIX, a política, sob o ponto de vista da tradição cristã católica, seria com participação direta da Igreja.

\section{REFERÊNCIAS}

A IGREJA e a instrução. A cruz. Rio de Janeiro, 25 jun. 1933, p. 1. Disponível em <http://memoria.bn.br/docreader/829706/3146>. Acesso em: 06 jan. 2019.

ALAMINO, M. de C. J. Na casa de Marta e Maria: um estudo sobre o Colégio Notre Dame de Sion em Petrópolis. 2008. Dissertação (Mestrado em Educação) - Universidade Católica de Petrópolis, Petrópolis, 2008.

ARRUDA, M. A. Formar almas, plasmar corações, dirigir vontades: o projeto educacional das Filhas da Caridade da Sociedade São Vicente de Paulo (1898-1905). 2011. 259 f. Tese (Doutorado em Educação) - Universidade do Estado do Rio de Janeiro, Rio de Janeiro, 2011.

AZZI, R. Os Salesianos no Rio de Janeiro. A implantação da obra salesiana (1884-1894). São Paulo: Salesiana Dom Bosco, 1982. (v. 2.).

AZZI, R. Os Salesianos no Brasil: a luz da história. São Paulo: Salesiana Dom Bosco, 1983. 
MARTINS, M. A. C.

BIGO, P. A doutrina social da Igreja. São Paulo: Loyola, 1969.

BRASIL, G. O regalismo brasileiro. Rio de Janeiro: Cátedra; Brasília: INL, 1978.

BRASIL. Decreto no 1.331-A, de 17 de fevereiro de 1854. Approva o Regulamento para a reforma do ensino primario e secundario do Municipio da Côrte. Disponível em: $<$ http://www2.camara.leg.br/legin/fed/decret/1824-1899/decreto-1331-a-17-fevereiro1854-590146-publicacaooriginal-115292-pe.html>. Acesso em: 8 jan. 2016.

CARVALHO, J. M. Cidadania no Brasil: um longo caminho. 19. ed. Rio de Janeiro: Civilização Brasileira, 2015.

CONCEIÇÃO, J. T. da. Internar para educar:Colégios-internatos no Brasil (1840-1950). 2012. 323 f. Tese (Doutorado em História) - Universidade Federal da Bahia, Salvador, 2012.

CONCEIÇÃO, Joaquim Tavares da. Colégios-Internatos nas páginas do Almanak Laemmert (1845 a 1889), Clio: Revista de Pesquisa Histórica, n. 31.1, 2013. Disponível em: <http://www.revista.ufpe.br/revistaclio/index.php/revista/article/viewFile/307/185>. Acesso em 26 mar. 16.

CONCÍLIO PLENÁRIO LATINO AMERICANO. (1899) Atas e Decretos. Biblioteca Electronica Cristiana. Disponível em: <http://multimedios.org/docs/d000021/ $\geq$. Acesso em: 18 jun. 2012.

CUNHA, P. M. C. da. Educação como forma de resistência: O caso da Irmandade de Nossa Senhora do Rosário e São Benedito dos Homens Pretos. 2004. Dissertação (Mestrado em Educação) - Universidade Federal Fluminense, Niterói, 2004.

DELLA CAVA, R. Igreja e Estado no Brasil do século XX: sete monografias recentes sobre o catolicismo brasileiro - 1919-64. Estudos CEBRAP, n. 12, p. 5-52, 1975.

DUTRA NETO, L. Das terras baixas da Holanda às Montanhas de Minas. 2006.

315f. Tese (Doutorado em Ciência da Religião) - Instituto de Ciências Humanas. Universidade Federal de Juiz de Fora, Juiz de Fora. Disponível em: $<$ http://www.bdtd.uff.br/tde_busca/arquivo.php?codArquivo=27>. Acesso em: 30 jan. 2012.

FRANCO, R. Pobreza e caridade leigas; As Santas Casas de Misericórdia da América Portuguesa. 2011385 f. Tese (Doutorado em História Social) - Universidade de São Paulo, São Paulo, 2011.

HILGENHEGER, N. Johann Herbart. Recife: Fundação Joaquim Nabuco, Editora Massangana, 2010. (Coleção Os Educadores). 
HÓSTIA, Á. de J. O Padre Siqueira; sua via e sua obra. Petrópolis: Vozes, 1957.

JÚLIO MARIA. O Deus desprezado. In: JÚLIO MARIA. O Deus Desprezado - A Graça. 2. ed. Rio de Janeiro: Boa Imprensa, 1934. pp 1-107

JÚLIO MARIA. Dom Bosco e o pobre. Communio, n. 28, 1986, p. 73-85.

LAGE, Ana Cristina Pereira. Escolas confessionais femininas na segunda metade do século XIX e início do XX: um estudo acerca do Colégio Nossa Senhora de Sion em Campanha (MG). Acervo Navegando na História da Educação Brasileira. Campinas: FE/ HISTEDBr / UNICAMP, 2006. Disponível em: $<$ http://www.histedbr.fe.unicamp.br/navegando/artigos_pdf/Ana_Cristina_P_Lage_Arti go.pdf>. Acesso em: 04 abr. 2016.

LE GOFF, Jacques. São Francisco de Assis. 12. ed. Rio de Janeiro: Record, 2013

LEÃO XIII. Aeterni Patris. 1879. Disponível em: $<$ http://filosofante.org/filosofante/not_arquivos/pdf/Aeterni_Patris.pdf $>$. Acesso em: 25 jun. 2012.

LEÃO XIII. Rerum novarum. 1891. Disponível em: <http://www.vatican.va/holy_father/leo_xiii/encyclicals/documents/hf_lxiii_enc_15051891_rerum-novarum_po.html $\geq$. Acesso em: 12 jul. 2010.

LEME. D. Sebastião. A Carta Pastoral de S. Em. Sr. Cardeal D. Leme quando Arcebispo de Olinda saudando os seus diocesanos. Petrópolis: Vozes, sd.

LIMEIRA, A. de M. O comércio da instrução no século XIX: colégios particulares, propagandas e subvenções públicas. 2010. 198 f. Dissertação (Mestrado em Educação) Universidade do Estado do Rio de Janeiro, Rio de Janeiro, 2010.

MARSHALL, T. H. Cidadania e Classe Social. In: MARSHALL, T. H. Cidadania, Classe Social e "Status". Rio de Janeiro: Zahar Editores, 1967. p. 57-87.

MARTINS, M. A. C. Padre Júlio Maria, a igreja do povo e a educação no final do século XIX. Anais do VII Congresso de Pesquisa e Ensino de História da Educação em Minas Gerais. Mariana: UFOP, 2013.

MOLLAT, M. Os pobres na Idade Média. Rio de Janeiro: Campus, 1989.

MOURA, L. D. de. A educação católica no Brasil. São Paulo: Loyola, 2000.

O PAIZ. Rio de Janeiro, 10 nov. 1900, p. 2. Disponível em:

<http://memoria.bn.br/DocReader/178691_03/1600>. Acesso em: 06 jan. 2019. 
MARTINS, M. A. C.

PASCHE, A. de M. L. Entre o trono e o Altar: sujeitos, instituições e saberes escolares na capital do Império brasileiro (1860-1880). 2014. 376 f. Tese (Doutorado em Educação) Universidade Estadual do Rio de Janeiro, Rio de Janeiro, 2014.

RODRIGUES, A. M. M. (Org.). A Igreja na República. Brasília: UnB, 1981.

PINHEIRO, A. Catequese indígena e educação do escravo e liberto: antídotos à imigração em "O Apóstolo". In: Anais dos Simpósios da ABHR, Vol. 12 (2011). Disponível em: $<$ http://www.abhr.org.br/plura/ojs/index.php/anais/article/view/89>. Acesso em 24 mar 2016.

PIO XI. Divini Illius Magistri. (1929). Disponível em: <http://www.vatican.va/holy_father/pius_xi/encyclicals/documents/hf_pxi_enc_311219 29_divini-illius-magistri_po.html>. Acesso em: 29 out. 2012.

RICOEUR, P. Tempo e narrativa. São Paulo: Martins Fontes, 2010. (v. 3).

SANTIROCCHI, Í. D. Uma questão de revisão de conceitos: Romanização Ultramontanismo - Reforma. Temporalidades, Belo Horizonte, v. 2, n. 2, p. 24-33, ago./dez. 2010. Disponível em: <www.fafich.ufmg.br/temporalidades $>$. Acesso em: 06 mar. 2011

SANTOS, J. A. A Trajetória da Educação Profissional. In: LOPES, E. M.; FARIA FILHO, L. M.; VEIGA, C. G. (Org.). 500 anos de educação no Brasil. 3. ed. 1. reimpr. Belo Horizonte: Autêntica, 2010.

SOARES, M. de Carvalho. Política sem cidadania: eleições nas irmandades de homens pretos, século XVIII. In: CARVALHO, José Murilo de; CAMPOS, Adriana Pereira (Org.). Perspectivas da cidadania no Brasil Império. Rio de Janeiro: Civilização Brasileira, 2011. p 409-434.

\footnotetext{
Marco Aurélıo CorrêA Martins: Possui graduação em Pedagogia pelo Centro de Ensino Superior de Juiz de Fora (1990), graduação em Filosofia pela Universidade Federal de Juiz de Fora (1993), mestrado em Educação pela Universidade Federal de Juiz de Fora (1999) e doutorado em Educação pela Universidade Federal de Juiz de Fora (2013). Atualmente é professor do Departamento de Fundamentos da Educação da Escola de Educação/Centro de Ciências Humanas da Universidade Federal do Estado do Rio de Janeiro - UNIRIO.

ORCID: http://orcid.org/0000-0002-3362-1300

E-mail: marcoaureliocorreamartins@smail.com
}

Este periódico utiliza a licença Creative Commons Attribution 3.0, para periódicos de acesso aberto (Open Archives Iniciative - OAI). 